\title{
The Quest for Teachers of the 'Right Stamp' as Prerequisite to Progress of Female Education in Eastern Bengal: The Partition Interlude
}

\author{
Asha Islam Nayeem*
}

\section{Introduction}

When the nineteenth century came to its glorious end, in Bengal, the storm surrounding the question of women's education had settled in favor of progress. Conditions for the spread of female education, however, were still precarious, to say the very least. The three chief deterrents to the spread of female education, as recorded in official documents, were: (a) the custom of early marriage, after which girls dropped out of school and more often than not lapsed into ignorance; (b) the system of purdah, the social custom which prevented grown up girls from venturing out of the house to attend school; and, (c) the lack of female teachers (Report on Public Instruction, 1899-1900).

The problem created by early marriage in relation to continuing education was addressed by the institutionalization of zenana education, the system of home teaching that had been prevalent in aristocratic families before, but had been turned into a properly guided institution through private and government agencies. The observance of purdah or seclusion of women from the outside world, on the other hand, was a creation of centuries of patriarchal domination encased in culture and tradition that would take very strong economic incentive, socio-political will and religio-cultural persuasion to break. By the beginning of the twentieth century, when the demand for female education spread, the same social custom that had denied girls access to education also resulted in the acute shortage of female teachers because the

\footnotetext{
${ }^{*}$ Associate Professor, Department of History, University of Dhaka
} 
creation of a pool of educated women had been prevented from which the supply of teachers could have come. Women's work was as much a disdainful thought as women's higher education. Thus, at the beginning of the twentieth century, in 1900, the Director of Public Instruction for Bengal, while stressing on the need for female teachers, laments, "We have indeed to reckon with the common prejudice, which suspects the respectability of any woman who would occupy the public position of a teacher in a public girls' school...In female education we have still to break ground" (Report on Public Instruction, 1899-1900, Proceedings Nos. 20-26).

The time to break new ground seemed to have arrived with the Partition of Bengal in 1905 that provided East Bengal, the region that is now Bangladesh, with the much needed administrative attention that had eluded the region due to Calcuttacentric socio-economic developments of the previous century. As the colonial rhetoric focused on social uplift schemes to justify the creation of the new province of Eastern Bengal and Assam, the newly appointed Director of Public Instruction (DPI), Henry Sharp, with the support of the Lieutenant-Governor, Lancelot Hare, resolved to attempt a breakthrough by inaugurating a massive enquiry into the state of female education in this region, to be followed up with innovative measures for reform. The grand reform plan involved the setting up of a powerful, representative body called the Female Education Committee (FEC) which was entrusted with the complete overhauling of female education in this region. The Committee attempted to tackle, among other things, ways of solving the problem of recruiting and training female teachers. This paper raises a discussion on the issues surrounding women's work like the questions of 'respectability' and social acceptance of a working woman. This issue, however, was a very sensitive one and the government wanted to exercise utmost caution. Jeopardizing the new-found friendship with the Muslim community was not a path the government wanted to tread on. That is why, in an attempt to strengthen the government's claim to legitimacy, an opinion poll on female education, the first of its kind in Bengal, was conducted. The Female Education Committee's work was to be based on the responses received from the survey. The results of this opinion poll, conducted in 1907, provide highly useful insight into the contemporary mind. 
The aim of this paper is to document this experiment of the British Raj with female education that has not previously been examined. The Committee's ideas and activities and the bureaucracy's reaction to those ideas form crucially important documents for charting the course of female education in the early $20^{\text {th }}$ century. These invaluable documents in the holdings of the National Archives of Bangladesh have so far escaped the notice of scholars. The paper also investigates the rhetoric of intention and implementation in the face of political reality in the case of the short-lived province of Eastern Bengal and Assam (1905-1911).

Bengal Education Department records throughout the nineteenth and early twentieth century are replete with comments of Directors of Public Instruction (DPI) and Inspectors of schools which identified that the lack of trained female teachers was a major impediment to the spread of girls' education in Bengal. An assessment by Henry Sharp finds that the lack of mistresses, trained or untrained, no training arrangements for mistresses and no Inspectress of Schools was "the most urgent question of all and one which must be dealt with at once" (Letter from DPI to Chief Secretary, Government of Eastern Bengal and Assam, 1906). A teachers' training facility would be attached to the Eden Female School, the only government funded English High School in Eastern Bengal in 1907. Prior to that, the work of training, in whatever form that might have been, was done entirely by the various missionary bodies working in Bengal, for placement in mission schools. The Director of Public Instruction, A. W. Croft, had noted in 1878 that the social classes from which teachers could be recruited were limited to two: Native Christians and Brahmos, and chiefly the former (Education Consultations 1878). The situation had remained unchanged after more than two decades of that statement. As early as 1863, a Female Normal School, a school for training teachers, was opened in Dhaka (Ahmed 82). However, after operating for almost a decade, on the recommendation of the then Inspector of Schools in Bengal for the South-East Division, C.B. Clarke, who would later become the Director of Public Instruction, the government closed the training school for female teachers on $31^{\text {st }}$ July, 1872 on the grounds that no trainees were available (Government of Bengal 1872). Yet, the Report on Public Instruction for 1869-70 records that twenty Hindu widows, of 
whom fifteen were from the "lower ranks" and five were from the "middle ranks" had trained in that institution (Government of Bengal, 1869-1870). As far as records can trace, Radhamani Debi, one of the first graduates of the Dacca Female Normal School, was appointed as a teacher at Sherpur Girls' School in 1866, on a monthly salary of thirty rupees (Borthwick 317). Even before that, one of the first recorded instances of a lady in Eastern Bengal taking up a teaching job was that of Bamasundari Debi of Pabna (Ray 29). She also trained other girls to become peripatetic teachers who went from house to house to teach the elderly women or young brides of the household who would never step outside the home, so would otherwise never attend any formal institution for education. Another pioneering lady of the early generation who took up teaching as a profession in the 1860s was Monorama Majumdar who worked in Barisal. She had to face a great deal of hostility for being a preacher in the Brahmo Samaj, the first woman preacher, according to available records (Borthwick 316). In 1878, she took up the position of second mistress at the newly established Eden Government Female School in Dhaka.

The Partition gave the new government of East Bengal and Assam the incentive to change the traditional backwardness of the province by creating more opportunities through the spread of education. The motive was not to enhance revenue collection, which was already very high, but to achieve a politically motivated uniformity in the imperial culture and control by transforming the East Bengal society and bringing the people of this region to the level of the other subjects of British India educationally and culturally. Though the loyalty of the Muslim gentry to the Raj was beyond question, their allegiance was of little value to the Raj if a strong support base from below could not be created. That support could come only when people below got the designed education of collaboration and competition, and become an antidote or "counterinsurgency force", as put by Ranajit Guha, with the 'enemies' of the empire, implying those resisting the $R a j$ for self rule (Guha 333). In view of the rising nationalist aspirations of the Hindu Bhadralok, East Bengal and Assam could make a strong colonial power base, if the hitherto neglected province could be transformed and brought into the folds of 'modernity'. For such a transformation, there was no other better way than to educate the people, both male and 
female. Education was not only to be the means of ensuring Muslim collaboration, as was done with the Hindus in the greater part of the nineteenth century, but also the most effective approach to establish the imperial culture in every hearth and home of the subject people. Thus, immediately after establishing the essential governmental institutions and paraphernalia of the new province, the LieutenantGovernor advised the DPI to proceed with the reform scheme and to establish a "representative" committee for constantly enlightening the government as to the best mode of removing obstacles to the spread of female education and evaluating people's attitude to its progress. The Lieutenant-Governor himself gave an outline of the new reform plan for the consideration of the proposed standing committee officially known as Committee on Female Education.

\section{Setting up the Committee on Female Education}

There is no doubt about the government's utmost seriousness about advancing education among the East Bengal population to a significant degree, and within a short period. From the imperial point of view, it was a political necessity to take a paternalist view of the most neglected people of East Bengal and to justify the partition to the people of the province. That was the only means to enlist the support of the people in favour of the partition and in organizing popular resistance to the anti-partition resistance movement of the nationalists. As mentioned earlier, education was identified as the positive strategy to materialize the paternalist move. But it seems that the imperial paternalism was not yet disposed to look at the projected development representatively and secularly. The doubt is sustained by the composition of the thinktank for chalking out the action program. It consisted of nineteen members. On the committee, seven members were government officials, including R. Nathan (Commissioner of Dhaka Division and President of the Committee), three big zamindars, Khaja Salimullah Bahadur of Dhaka, Syed Nawab Ali Chaudhuri of Dhanbari and Rai Dulal Chandra Deb Bahadur of Sylhet, wellknown for their loyalty, two public figures known for their loyalty to the Raj, three Christian missionary societies and four missionary female teachers. Community-wise, eight were Hindus, eight were Europeans and three were Muslims. The Muslims formed the vast majority of the province. Then why were there only three members 
on the Committee? To raise a 'counter-insurgency' force to contain the anti-partition agitation, government had been keen to get through the message that the Muslims would be greatly benefitted from the creation of a new province. The composition of the Committee contradicts this assertion. But it must be recognized that all Bengal members were handpicks of the paternalist rulers and they were there to brace the official steps and moves against opposition, if any. Quite noticeable and conspicuous is the presence of so many Christian missionary persons and institutions on the Committee. Practically, while the high officials on the Committee were unlikely to give necessary time due to their official and other preoccupations, others were notables who were too exalted to attend Committee meetings and contribute. Under the circumstance, it was only the evangelicals who were to take the helm of the affairs of the Committee. In 1911 the composition changed entirely. The Committee was reconstituted to include more female members. When the FEC met in 1911 in Shillong, there were twelve female members in a committee of twenty-five.

The inaugural meeting of the Committee on Female Education was convened on 26 February, 1908, in Northbrook Hall at Dhaka. The discussions continued until 29 February, 1908. The Lieutenant Governor's message to the meeting was that the Committee should not only inaugurate proposals, but should also monitor their effect and advise Government on their progress. Individual members of the Committee were entrusted with particular branches of enquiry and several local sub-committees were formed to assist in making recommendations to the government on ways to improve the state of women's education in the province. The Committee met every year from its inception in 1908 until the annulment of Partition in 1911 and then met once in Calcutta in 1913. Ostensibly, the committee was entrusted with great trust and responsibility, and the Committee also took the assignment very earnestly. At the inaugural session, the Committee was handed the results of the public opinion poll on which the recommendations were to be based. The responses to the questionnaire bear the most interesting revelations about contemporary attitudes regarding women's entry into the public domain. 


\section{The Questionnaire}

The British regime had, since the $18^{\text {th }}$ century, relied on the gathering of information to understand the dynamics of the society they ruled over. The gamut of information the colonial state gathered, however, was concerned about how to extract the maximum amount of revenue and how best to administer law to maintain the colonial order (Wilson). The first debate on education policy was a long one, beginning from 1820 and ending in 1835 with the triumph of the Macaulean thought of education. This was the time when the great Bengal intellectuals and activists like Mirza Abu Talib Khan, Rammohan Roy, Raja Radhakanta Deb, Bhavanicharan Bandopadhya, Ishwar Gupta and others lived. But none of them was called upon to join the debate. It was un-imperial to consult a 'subject' for deciding imperial questions. As subjects, they saw with silence the imperial arrogance with which Macaulean ideology and prose of education were adopted. The Macaulean system of education, in which women did not exist, continued to operate until Wood's Education Despatch (1854), which provided a guideline for native education from the primary to the highest levels. In the Despatch, there was provision for women's education as well, though in quite vague terms. The nineteenth century had ushered in the age of social reform that made women visible for the first time in the discourse of colonial India. This was reflected in the deliberations and recommendations of the Indian Education Commission of 1882 where the question of female education featured with due prominence (Nurullah, Naik). The survey conducted in 1907 on the basis of a questionnaire consisting of twenty-four questions relating to female education was not as massive in scale as the enquiries made in 1882 but certainly it was the first where the focus group was the Muslim majority population

of Eastern Bengal in general and the female population in particular.

The set of twenty-four questions were circulated among a medley of officers of the government, both European and Indian, Christian missionaries, and civilians (Hindu and Muslim) who were locally influential. Among the respondents, there were twenty-two Europeans, sixty-four Hindu and nineteen Muslim gentlemen. Of the twenty-two Europeans, six were missionaries working in Dhaka, 
Rajshahi, Sylhet, Faridpur, Silchar and Nowgong. Only two women were selected to answer questions related to female education. Both of them were white Christian missionaries, one was Miss E.L. Williamson, working in the Baptist Zenana Mission in Dhaka and the other was Miss E.M. Lloyd, working in Silchar. The questions ranged over all the problems and issues that had been debated concerning female education since the Hunter Education Commission of 1882, such as, how to strengthen the institution of zenana education, how to open new schools in urban and rural areas, whether the idea of boarding schools would be received favorably, what the curricula should be, how effective management committees could be formed, how the help of locally influential persons might be obtained, how to ensure the help of Indian ladies, what should be the criteria for offering scholarships, what would be the best way to inspect girls' schools, and many more related to girls' education. For the purpose of this paper we shall be reviewing the questions related to the issue of female teachers.

Out of 24 questions, eight questions, beginning from question 12 , were directly concerned with female teachers and the overriding issue was where to recruit female teachers from and if recruited, how to solve the question of respectability and social acceptance, how to train the teachers, whether widows would be suitable candidates to be trained as teachers, whether wives of school teachers could run girls' schools, etc. The questions and the responses make for highly interesting material on restructuring the social taboos, tradition and attitudes that ensured complete control over women's lives.

\section{Recruitment and Training of Teachers of the 'Right Stamp'}

It was question number twelve that asked: 'How can teachers of the right stamp be recruited? Should the recruitment be confined to certain classes and castes?' In answer to this vital question, B.C. Allen, the Magistrate of Dhaka summed up the problem thus: "Teachers are very difficult to get. Hindus are practically out of the question. Brahmos are quite suitable, but supply is limited. Native Christians are fairly numerous. Something might be done by buying little Christian girls from their parents and training them up at Boarding schools. Muslim female teachers 
might possibly be obtained from Behar" (Education Proceedings 1908, p.137). The suggestion of buying little Christian girls from their parents is appalling to the senses. But conversions into Christianity happened mostly among the poorest of the poor. How the Christian conversion worked and to what extent the missions went to procure such conversions is not within the purview of this paper. A.W. Botham, Deputy Commissioner of Sibsagar says, "While supply is so small, very liberal time should be offered for suitable teaches. Recruitment need not be restricted to any particular class or caste (137)." It was quite understandable that the European respondents would have no class and caste preferences, but that kind of leniency could not be expected of the more orthodox Hindu and Muslim respondents. Maulvi Ahsanullah, Officiating Inspector of the Chittagong Division claims that preference should be given to candidates of the same caste to which the majority of the girls under instruction belong. A well thought out answer came from an officer of the Education Department, Babu Rajeswaar Gupta who was the Head Master of the Rangpur Training School. In his opinion, teachers of the right stamp could be recruited if: (a) the pay was attractive; (b) schools were set up in selected places, and, (c) the female teachers were allowed to be absent during the time of inspection by male Inspectors. Liberal pay was suggested by the Deputy Commissioner of Kamrup, Major D. Herbert too. The retired Assistant of Schools for Dhaka, Babu Kumud Bandhu Bose also thought that adequate remuneration would bring in a fair supply of qualified female teachers. As a retired school Inspector, it can be assumed that he was speaking from a position of an informed respondent. However, his colleague, Babu Nava Kishore Sen, retired Deputy Inspector of Schools for Brahmanbaria thought that for the present, the Christian and Brahmo communities were the only communities where female teachers could be looked for. Reverend Mr. Hamilton of Rajshahi considers Baishnavis most unsuitable for teaching posts. The Commissioner of Rajshahi, Mr. F.C. Henniker advises patient search and enquiry to find teachers of the 'right stamp'. $\mathrm{He}$ proposes to recruit European ladies trained in England and retired male teachers of 'good character' to teach at girls' schools.

The demand for teachers greatly exceeded the supply in the first half of the twentieth century. So, when the Female Education 
Committee recommended to the government that at least ten new primary schools of an improved type in each district and one good secondary school at the headquarters of those districts, either a middle vernacular school or an English school be set up on an urgent basis, the problem of staffing those schools was a major concern indeed. Hiring elderly male teachers was a plausible option initially, but eventually all girls' schools had to, on principle, be entirely staffed by female teachers. The Female Education Committee, to make do with the available resources at hand, decided not to raise the bar high as to how qualified the teachers should be. To qualify for the post of a head mistress in a secondary school, a very suitable mistress would be, the Committee decided, a lady who has read up to the Middle Vernacular standard (classes V, VI and VII) and has preferably received training in a special training school. She should be paid 40 rupees, 2 anna and 50 paisa a month. As for the rest of the female teaching staff, the ordinary rule to be observed was that, the mistresses should have studied at least one stage higher than the girls they are to teach. Accordingly, the second mistress should have read up to the middle vernacular standard or its equivalent and would be paid 30 rupees per month; the third mistress should have read up to the upper primary or its equivalent and be paid 25 rupees a month and the fourth and fifth mistresses should have read up to the lower primary or its equivalent, and be paid 20 rupees a month. There was no provision for the teaching of English at a Middle Vernacular school and special arrangement would have to be made should the demand for English teaching arise (Assam Secretariat, Sylhet Proceedings).

The more tenacious effort had to go into creating an environment that would attract women to join as primary school teachers as the greater demand was for the primary level education. The task of recruiting teachers entailed a three-fold procedure. First, enquiries needed to be made to ascertain which women educated up to the upper primary standard or its equivalent were willing to take service in schools. Secondly, the prospects and the probable terms of employment had to be prepared and they also needed to be prepared in a manner advantageous to the candidates. Thirdly, it remained to be considered through what agency the concerned authorities should make it known that mistresses are required and 
how the particulars regarding applicants were to be ascertained (Bengal Education Proceedings, 1904).

Creating a pool of prospective candidates for teaching was a challenging task and the Education Department could not afford to make class distinctions under the given circumstances. Therefore, the FEC recommended that government grant liberal stipends to women of all classes for completing their education to the end of the middle vernacular stage on the condition that they would serve for two years as a teacher. The rate of stipends should be 8 rupees per month in Class V, 9 rupees in Class VI and 10 rupees in Class VII of the Middle Vernacular course. However, sufficiently attractive though the stipends may be, the Committee feared that unless the middle vernacular schools were entirely staffed with female teachers, guardians would not allow grown up girls to attend those schools. But where were such teachers to be found? It was recognized that special training schools afforded the best agency for the recruitment of teachers. The training classes attached to the Eden School was the only training facility for teachers in the whole of Eastern Bengal. That institution had trained 25 pupils by 1911 (Education Proceedings, 1912). Of them, nine were Brahmos, six were Hindus, seven were Christian, two were Muslim and one was Parsi. Seven of the trainees were widows, four were married and the rest were young girls. At the end of their training, all of them were employed in government and mission schools in Dhaka, Barisal, Faridpur, Mymensingh and Comilla. However, a lack of Muslim trainees remained a matter of concern for all concerned. The Hon'ble Khan Bahadur Syed Nawab Ali, zaminder of Dhanbari, Tangail, who would later be instrumental in the establishment of the University of Dhaka, mentions: "As a matter of principle, teachers should be always women. It would certainly be extremely difficult to attract Muslim girls to schools which will not only have, out and out, an entire staff of lady teachers, but which would not maintain, due regard to Purdah" (Education Proceedings 1908, p.146). The minimum qualification for applying for a teaching job was a primary school certificate. Even that, however, was not forthcoming in the foreseeable future.

Question fifteen asked whether it would assist the cause of female education to secure widows to be educated and trained, and 
if so, by what agency, and, question sixteen asked whether elderly or retired male teachers would be found suitable for the job of teaching small children. That the services of widows and retired male teachers would be of great value was acknowledged by all the respondents. Regarding widows, however, most respondents thought that under the present state of Hindu and Muslim societies, no widow would come forward in search of work and volunteer for training. As for the service of elderly male teachers, the Head Master of the Dacca Madrassah Maulvi Zahirul Haq rightly pointed out that that was in fact the agency by which the girls have traditionally received religious instruction in the numerous madrassahs all around the province, so there should be no objection to use that option in formal schools.

Question seventeen was concerned about whether wives of village school teachers may be given an allowance from the District Board to keep a small girls' school in connection with the boys' school wherever it was possible to do so. To that, the respondents rightly pointed out that wives of village school masters were not necessarily educated. However, where the wives were educated, majority of opinion was in favour of giving them an allowance to keep a small girl's school in connection with the boys' school. The missionary ladies and gentlemen unanimously vetoed this idea. Some Hindu and Muslim gentlemen also did not approve of the scheme on the grounds that it involves either the neglect of household duties or of the school; and most usually the latter. When the matter was presented to the Female Education Committee for a solution to be found, the Committee decided that the greatest hope of obtaining village school mistresses was to be found in the male teachers' female relatives. To entice male teachers into training their female relatives to qualify for a teaching job, a reward of 100 rupees was to be awarded for every successful candidate. A training school was to be opened in Comilla at a monthly recurring expenditure of 800 rupees. The Committee also recommended that female teachers be paid more than male teachers because the female teacher would have to make arrangements for a male or elderly female relative to live with her and that would cost her more.

As an alternative solution to the problem of the dearth of female teachers, question eighteen asked whether mixed primary 
schools of boys and girls under respectable pundits who would draw a special allowance for the girls would be popular and successful. Most of the private Hindu and Muslim civilians opposed the idea. The officials of the Education Department, on the other hand, not unsurprisingly, supported it wholeheartedly, as they were acutely aware that ground realities would not change overnight, and that the girls' schools could not be staffed entirely with female teachers in the immediate future. The supporters of the idea, however, insisted on separate rooms for the girls so that purdah could be maintained. Any suggestion that did not comply with the social norms of the times was bound to fail.

\section{The 'Respectability' of Teachers}

Perhaps the more pressing question than where to procure female teachers from was the question of how to ensure that the teacher commands the faith and respect of society. The perceived threat of women as sexual beings is ever present in the male psyche, thus the control over women's sexuality lies at the very core of patriarchal domination. The creation of the notion of 'respectability' is an important component of domination as it puts considerable restrain on woman's mobility. Under colonial rule, patriarchy was strengthened by the male's loss of power in the public sphere (Chakravarty, Majumdar). As Ashworth puts it, "Male control of the female becomes more and more significant in the search for a political identity that will be headed by power-holders. It requires women to express submission in order to 'belong' to, or to 'deserve' the protection of, the community" (Ashworth 20). The respectability or acceptability of teachers was of utmost importance, which was the reason why question nineteen asked: 'Under what conditions must women teachers in Model and District Board schools live in order to enjoy public confidence?' The answers, which were compiled in a large volume of the Education Proceedings of the Government of Eastern Bengal and Assam, were quite predictable. A government pleader and Member of the Legislative Council, Eastern Bengal and Assam, the Hon'ble Rai Dulal Chandra Deb Bahadur of Sylhet considers 'chastity' as the highest parameter by which to judge a female teacher. The teacher, he says, if she be a married woman, must live with her husband. He also adds, "Chastity in a woman is the only way for her to win 
public confidence and I do not know any means which can be devised to make a woman chaste if she does not like to be so" (GEBA Education Proceedings 225). Babu Kali Prasanna Chakravarty, a talukdar, says, "Female teachers in order to enjoy public confidence must live in the style in which other respectable or orthodox ladies of the Mahalla lives" (225). Babu Navanath Barua, Siristadar of Nowgong, Assam, thought, "The teachers should live in such a manner as will create least suspicion. They should not allow male visitors to visit their houses under any circumstances. Male visitors visiting the school should be allowed under strict rules" (GEBA Education Proceedings 226). The Secretary of Tezpur Girl's High School (of Assam), Babu Mon Mohan Lahiry comments, "The female teachers must live in decent style. They must not freely mix with men and must not move publicly from house to house on foot" (GEBA Education Proceedings 224). The Secretary of Alexander Girls' High School of Mymensingh, J.M. Das presents a well-balanced judgment when he says, "It is purity of character and not any particular mode of living that the people require. Such matters must be left to be determined by the school committee with reference to the circumstances of each locality" (GEBA Education Proceedings 225).

In the opinion of the missionary historian, Ruth Brouwer, the Christian missionaries who came to India from the United Kingdom, the U.S.A. or Canada, irrespective of denomination, were transformed by Indian culture and adapted themselves to the needs of the people they served (Brouwer). The missionaries did not embark on bringing radical change in social customs. Instead, they concentrated just on personal beliefs. Thus, their answers to the question on how female teachers could gain respectability did not differ from the answers given by local patriarchs. Miss E.M. Lloyd, a missionary working in Silchar, Assam, wrote that: "If the teachers do not live with their parents or guardians, a house should be provided for them on the school compound" (GEBA Education Proceedings 224). Rev. P.H. Moore of Nowgong wrote that living with a husband, a parent, or other relatives is the best safeguard against the suspicion that pervades society at large. Here is the outright mention that society was deeply suspicious regarding the intentions of women. Reverend J. Pengwern Jones of Sylhet wrote 
that if the female teachers live with any respectable person in charge, or, better still, a man and wife in charge, the public will be satisfied. Miss E.M. Williamson of the Baptist Zenana Mission of Dhaka wrote: "In towns women teachers should live together in a town, controlled by a responsible local committee. In the villages, only married women whose husbands are free to take the oversight of the home, and hold a respectable position in the community, will be employed" (GEBA Education Proceedings 224). The responses of the Christian missionaries from Europe demonstrates a sympathetic understanding of the society they were working in and shows how careful they were not to upset the delicate balance between their mission to proselytize yet maintain a secular view where social reforms were concerned.

The nine Muslim gentlemen who were selected to give their opinion were: the Hon'ble Khan Bahadur Syed Nawab Ali, zamindar of Dhanbari and member of the Legislative Council of Eastern Bengal and Assam; Nawab Syed Abdus Sobhan Chowdhury, Nawab of Bogra; Maulvi Syed Abdul Majid, President of Anjuman Islamia; Maulvi Musharruf Hossain, Pleader and Vice-Chairman of the Jalpaiguri Municipality; Maulvi Nuruddin Ahmed, Member of the Local Board, Nowgong; Maulvi Yaquinuddin Ahmed, Government Pleader, Dinajpur; Maulvi Fazlul Haq, who, in 1923 would become the first Indian Education Minister of Bengal, and subsequently, Chief Minister; Maulvi Kutubuddin Ahmed, and, Maulvi Momtazuddin Ahmed. The unanimous response from these gentlemen was that female teachers "...should live with at least some members of their families in quarters provided for them in or near the school compound. They may also live in the house of some relative if any, or respectable person of the locality, but in no case must they live alone" (GEBA Education Proceedings 228). The Magistrate of Dhaka, B.C. Allen, Esq. ICS, summed up the predicament of the female teacher thus: "If they live as they do in the Eden Girls' School in a body together under a respectable lady superintendent they enjoy every confidence. It would also do if Brahmos or native Christians lived in some respectable Hindu family" (GEBA Education Proceedings, p.218). The message most certainly came through that living alone for a woman could never be an option if she sought respectability. Question twenty somewhat overlapped with the previous question 
as it asked: 'What establishment must be provided on the premises to secure such conditions?' Most of the answers were similar to that of the answers to question nineteen. The final verdict was that female teachers must live under purdah, in free quarters attached to the school with female servants or in the house of respectable families under the control of the Managing Committee. Only by restricting the movements of women who ventured out into the public space and by placing them under strict surveillance could society hope to restrain the 'new woman' created by colonial modernity. Women who broke the shackles of the 'old patriarchy' by acquiring education fell victim to a 'new patriarchy' that insisted on women being maintained in a dependent and subordinate status within Indian society (Walsh).

\section{The Peripatetic Mode of Teaching}

The informal peripatetic mode of teaching that got the cognitive of 'zenana education' in the colonial era was developed by the Christian missionaries in the 1840s. 'Zenana' is a Persian word meaning interchangeably woman or the private part of a household reserved exclusively for women. Traditionally, girls of aristocratic families would receive instruction at home from female tutors (called ustadnis) who would go from home to home, teaching zenana inmates the rudiments of religion, and basic household accounting. When the Christian missionaries failed to attract girls from the upper class, the class they most wanted to influence, to attend the mission schools established since the 1820s, they resorted to peripatetic teaching as the only alternative for gaining access to that class (Ghosh).

The zenana education system grew into a full-fledged institution enjoying government patronage since the Education Commission of 1882, popularly known as the Hunter Commission, recommended that peripatetic governesses should receive grant-inaid and zenana pupils should receive scholarships as encouragement (B.B. Roy, P. Ray). By the beginning of the twentieth century the demand for zenana teachers had far exceeded the supply, thus prompting government to initiate new experiments in zenana education. In the Indian Education Policy of 1904, provision was made for a new system of peripatetic teaching where 
the teacher, instead of making house-to-house visits to several homes, would visit one centre where the ladies would gather to receive instruction. This new method was called the central gathering scheme, or, alternatively, the mahallah system. An estimate puts the number of girls and women of Eastern Bengal receiving instruction under the new scheme at twelve hundred (Assam Secretariat, Report on Work of Zenana Governesses Up to Date 202), which was not an unsatisfactory number given the circumstances regarding the stress on maintaining purdah and the general aversion to the idea of girls attending formal schools. Question number fourteen of the questionnaire enquired how peripatetic governesses could be recruited and how best they could be educated and trained. Most respondents believed that although at present governesses could be recruited from within the Christian and Brahmo communities only, if liberal stipends were provided, widows and also married women of respectable Hindu and Muslim families may be permitted to be trained to be peripatetic governesses by their guardians.

The contribution of the missionaries to the spread of female education earned them a prominent place in the Female Education Committee. When the number of female members was increased in 1911, four new Christian missionary ladies were added to the previous four, bringing the number to eight. They advised the government on formulating curriculum, preparing readers and developing ideas on how to improve conditions for better administration and management of policies towards the spread of female education.

\section{Conclusion: An Appraisal of the Female Education Committee (FEC)}

A general review of girls' education in Bengal made in 1905 had revealed that,

...everything points to the fact that we are on the eve of a large expansion of education for women and girls. The people are willing to welcome such an expansion provided that progress proceeds on lines that are not antagonistic to their conservative instincts, with which sympathy should be shown. The policy must not be destructively radical, 
but progressively conservative (Report on Public Instruction in Bengal for 1905-06, p.6).

The composition of the FEC and the people selected for the survey conducted with the questionnaire ensured that recommendations coming out from that Committee would be 'progressively conservative', yet not be 'destructively radical.' The lasting contribution of the FEC remains the exhaustive reports of the myriad of sub-committees appointed to enquire into every aspect of female education in Eastern Bengal that provides detailed information in the field that no report of the Director of Public Instructions for undivided Bengal provided before. The problem of the training of teachers, the necessity for increasing the salaries of female teachers, the importance of bringing the accommodation facilities of teachers into consideration, etc. were aspects that hitherto had failed to attract the necessary attention of the authorities.

However, an inherent weakness of the FEC was that, it was entrusted with the task of making recommendations only, with no power or mechanism for implementing them. The funds that would be needed to be allocated sounded so staggering to the Chief Secretary that he wrote to the Lieutenant-Governor that:

\footnotetext{
These estimates of the total cost of the recommendations of the Female Education Committee are interesting mathematical exercises. But they need not disturb us, I think, as they represent merely an ideal to which we may aspire, but which we cannot hope to reach, and it is probable that the scheme now set out, will be modified in many respects, long before we come within reasonable distance of its realization (Assam Secretariat, Sylhet Proceedings, p.4).
}

The idea of the Female Education Committee was born of genuine altruism and its work was done with utmost sincerity, but the entire work of the representative body was tucked away under the gross cover of imperialist political rhetoric. The Marxist historian's explanation for the failure of the Committee to see the implementation of the ambitious plans it had laid out for the government would be that such failures were a recurrent phenomenon of colonial rule everywhere. From the Marxist perspective, the failure of the Committee was nothing but the 
essential inability of a nascent middle class to bring about social transformation within a hegemonic colonial structure (Chatterjee 96). Any such attempt would have to rely heavily upon the backing of the colonial ruler. In the case of the FEC, the whole cause turned into an intellectual exercise that fell victim to the complex interplay of colonial rhetoric and political expediency. The Female Education Committee ceased to exist when the partition of Bengal was annulled in 1911. Nevertheless, within that short period, the emphasis placed on the importance of teachers had much to do with transforming the old deep-seated disdain for woman's paid work into complacent acceptance. The partition interlude opened new avenues for members of the ashraf class like Syed Nawab Ali Chaudhuri to play an active role in the campaign for the extension of female education among the Muslims. The most positive legacy of the experiment of the Female Education Committee, however, would be the new efforts to consult widely on controversial aspects of educational policy and to encourage female participation on central and local committees and boards. The contributions of individual women on these committees laid the foundation for the new woman's participation in the socio-political arena in a more worthwhile manner.

\section{Works Cited}

Ahmed, Sharifuddin. Dhaka: Itihas O Nagar Jibon, 1840-1921 [Dhaka: History and Urban Life, 1840-1921]. Dhaka: Academic Press and Publishers Limited, 2001. Print.

Ashworth, Georgina. A Diplomacy of the Oppressed: New Directions in International Feminism. London: Zed Books Ltd., 1995. Print.

Assam Secretariat, Sylhet Proceedings. Education Department. 'Report on female education in the Province of Eastern Bengal and Assam.' File No. E-946 of 1909, April 1910, Nos. 1-8. Dacca: Government of Eastern Bengal and Assam, 1909. National Archives, Bangladesh. Print.

-. 'Proceedings of the Meeting of the Female Education Committee for Eastern Bengal and Assam held at Dacca on the 26th 
of February, 1908.' File No. E/946 of 1909. Dacca: Government of Eastern Bengal and Assam. National Archives, Bangladesh. Print.

-. 'Report on Work of Zenana Governesses Up to Date.' File No. E-946 of 1909, April 1910, Nos. 1-8. Dacca: Government of Eastern Bengal and Assam, Education Department (A) Proceedings, 1909. National Archives, Bangladesh. Print.

Croft, A.W. Director of Public Instruction. 'Letter from the DPI to the Secretary to the Government of Bengal.' Education Consultations (A) Proceedings. Calcutta: Government of Bengal. General Department Education Consultations, July, 1878 to 1879. Print.

Roy, Benoy Bhusan Pranati Ray. Zenana Mission: The Role of Christian Missionaries for the Education of Women in Nineteenth Century Bengal. Delhi: Indian Society for Promoting Christian Knowledge (ISPCK), 1998. Print.

Ray, Bharati Sekaler Narishiksa: Bamabodhini Patrika, 1270-1329 Bangabda [Women's Education of Those Times: Bamabodhini Patrika, 1270-1329, Bengali Calendar.] Kolkata: Kolkata University Women's Studies Research Centre, 1994. Print.

Borthwick, Meredith. The Changing Role of Women in Bengal, 1849-1905. Princeton: Princeton University Press, 1984. Print.

Brouwer, Ruth Compton. New Women for God: Canadian Presbyterian Women and India Missions, 1876-1914. Toronto: University of Toronto Press, 1990. Print.

Chakravarty, Dipesh. Provincializing Europe: Post-Colonial Thought and Historical Difference. New Delhi: Oxford University Press, 2001. Print.

Chatterjee, Partha. Empire and Nation: Essential Writings, 19852005. New Delhi: Permanent Black, 2010. Print.

Ghosh, Suresh Chandra. The History of Education in Modern India, 1757-1998. Hyderabad: Orient Longman Ltd., 1995. Revised edition in 2000. Print.

Government of Bengal. Education Department (A) Proceedings. 'Report on Public Instruction in Bengal for the year 1905-1906.' 
File No. 8-R-1/5, Nos. 138-139 . Calcutta: Government of Bengal, November 5, 1906. Print.

-. Education Department. Education (A) Proceedings. 'The Indian Education Policy, 1904.' File No. 10-0/16, Nos. 50-51. Calcutta: Government of Bengal, June 1904. Print.

- General Department, Education Branch. Education (A) Proceedings for 1872, Nos. 60-61. Calcutta: Government of Bengal. West Bengal State Archives. Print.

-. General Department, Education Branch. Education (A) Proceedings. 'General Report on Public Instruction in Bengal, 1899-1900.' File 8/R/4/1-5, Nos. 20-26. Report of the Assistant Inspector of Schools, Dacca Division. Calcutta: Government of Bengal, 1901. Print.

Government of Eastern Bengal and Assam. Education Department (A) Proceedings. 'Answers to Questions Relating to Female Education.' File No. E/349 of 1908, Nos. 125-143. Dacca: Government of Eastern Bengal and Assam, April 1908. National Archives, Bangladesh. Print.

-. Education Department. Education (A) Proceedings, January 1912. 'A Note on the Training Class Attached to the Eden High School for Girls, Dacca.' File No. E/25-E, Nos. 53-56. Dacca: Government of Eastern Bengal and Assam. National Archives, Bangladesh. Print.

Guha, Ranajit. Elementary Aspects of Peasant Insurgency in Colonial India. New Delhi: Oxford University Press, 1983. Print.

Majumdar, Rochona. Marriage and Modernity: Family Values in Colonial Bengal. New Delhi: Oxford University Press, 2009. Print.

Nurullah, Syed J.P. Naik. A Student's History of Education in India. Bombay: Macmillan and Company Limited, reprinted in 1974. Print.

Sharp, Henry Director of Public Instruction, Eastern Bengal and Assam. Letter to the Chief Secretary of the Government of Eastern Bengal and Assam. Assam Secretariat, Sylhet Proceedings: Government of Eastern Bengal and Assam. General Department, Education Branch (A) Proceedings, January, 1906 to March, 1908. National Archives, Bangladesh. Print. 
Walsh, Judith. Domesticity in Colonial India: What Women Learned When Men Gave Them Advice. New Delhi: Oxford University Press, 2004. Print.

Wilson, Jon. "The Making of a Colonial Order: Information, Uncertainty and Law in Early Colonial Bengal." Journal of the Asiatic Society of Bangladesh (Humanities) (June 2004, vol. 49, number 1), pp. 61-80. Print. 